\title{
TIME, SPACE AND THE SOCIAL LIFE NEW INTERPRETATION OF CEMETERIES IN THE CITY
}

\begin{abstract}
The article reveals the issue of time recorded in the urban space, which determines the specific rhythm, continuity and passing of consecutive generations and their social relations. Presented research results focus on cemeteries and appear to be helpful in better understanding of their identity in the city structure, as well as the factors shaping their perceptions by individual people. Qualitative research methods have been applied, in particular: visual materials (photos) analysis and the semantic field analysis.

It seems that the use of images and narratives opens up new possibilities for human geography, new sources of spatial exploration. The problem undertaken in the article is important both from the cognitive and practical perspective related to the appropriate shaping of the city space - modern, yet at the same time not rooted out of the tradition and identity of a particular place, where people would feel good, being able to find both a reference to the past and to the future.
\end{abstract}

Keywords: cemetery, place, space, time, cognition, human geography.

\section{Introduction}

Considerations concerning time as an essential attribute of reality and human cognition have been made for ages and are still vivid and vital. Although there is no uniform - broad, yet common, conception of time in social sciences, the reflections which are drawn from the works by representatives of different disciplines constitute an important voice in the discussion started in the second half of the $20^{\text {th }}$ century over various approaches to time, which human geography frequently refers to (see further: Tobiasz-Lis 2016).

The issue of time being experienced, recorded and read by urban dwellers was touched upon by K. Lynch (1972) in his book What time is this place? One might risk a claim that this work serves as a supplement to the author's earlier book entitled The image of the city (1960), which has shed new light in urban studies conducted by various researchers: architects, geographers, sociologists, psychologists, drawing their attention to the issues of experiencing, perceiving, 
remembering and projecting space by its users. The author noticed himself that a number of parallel statements which he had formulated on social representations of city space may also be attributed to social representations of time in this space.

It is evident that we should think of an environmental image that is both spatial and temporal, a time-place, just as we must design settings in which the distribution of qualities in both time and space are considered. Places are seen in the mind as changing or apparently static; their character and activity vary rhythmically; they connect the past and the future (Lynch 1972: 242).

The aim of this paper is to present the notion of time in urban space, reflected in particular places - cemeteries. Time is considered here from a broad perspective, as a basic element of urban reality and human cognition, specific rhythm of its usual and unusual functioning, continuity and evanescence of certain spatial structures - from the entire systems to small details; being an effect of changing social relations and serving as a "mirror" for the following generations. At the same time, urban space always contains elements which seem to "preserve" the changing surroundings. Preserved spatial structures, monuments, old parks, individual trees, memorial tablets - serve as the signs of the past which create the identity of the place and its inhabitants.

The paper contains an introduction, theoretical considerations over different traditions in applying the notion of "time", both in human geography and in related disciplines, which serve as a background for subsequently presented results of the empirical research on the relations between space and time in a city, methodological issues and discussion on research results.

\section{Time as a subject of interest in social sciences}

The basis for philosophical considerations concerning the notion of time is depicting it as a chronological series encompassing the past, presence and future, which become distinguishable thanks to people's memory, current perceptions and expectations. The psychology of time examines individual differences in temporal behaviors, orientation in time and time horizon of individuals. What follows from the research conducted by psychologists is the fact that people are far from perceiving time in a linear manner (Bajcar 2000). Works within the scope of sociology, on the other hand, may be divided into two trends of research conducted on the category of time. On the one hand, there is the issue of time budgets, free time and work time, where we consider a quantitative measurement of time units devoted to various kinds of everyday activities of individuals or entire social groups ${ }^{1}$. This research, associated with the then-predominant

${ }^{1}$ This trend of research refers to the school of time geography developed in the 1970s by $T$. Hägerstrand, who examined the use of time and ecologic organization of the Swedish society. 
physical approach to a society, does not say anything whatsoever about the specificity of time as an element of culture, social awareness, manners of thinking and evaluating. In this case, time is uniform, dividable, passes equally, the time of classical physics and common awareness shaped by modern Western culture - time measured by the clock and calendar. On the other hand, there is an area of research in sociology which treats the category of time itself as a subject for an analysis, an autonomic issue - not only a dimension of social phenomena, but rather a phenomenon itself. Thus, time is understood here as a socially and culturally changeable phenomenon, multilaterally conditioned, which cannot be reduced to simple quantitative indicators and characteristics. Such aspects as social issues, conventions, values and meanings connected with time are encompassed in this case in the social life. Time is a socially subjective category, experienced in particular social contexts. There occurs a characteristic shift from the concept of time as a measure to the concept of time as a value, a shift from economic time to anthropologic time.

Anthropologists and ethnographs are interested in the notion of time and the expectations associated with it as an element of the culture of societies. Some studies have been conducted with reference to the past, present and future as well as the manners of experiencing and measuring time (Leach 1950, 1956, 1961; Lévi-Strauss 1969, 1970). The results of the studies corroborate the fact that the issues of duration and evanescence, succession and change, as well as cyclical and linear manners of understanding time appear in all human societies, yet they vary in terms of their significance depending on the society.

Architects and urbanists identify time with a movement symbolising the evolution and internal energy of especially urban spaces. Time, perceived here as the fourth dimension, transforms all three-dimensional and three-directional transformations into four-dimensional and four-directional at the same time, dependent on time, its passing and pace. These transformations may be observed on the basis of the territorial expansion of cities, transformation of their internal structures, disappearance of old elements and emergence of new elements. A city is a rich, movable and changeable "mosaic in terms of the scale, size, age, form and character of the elements, collage of shades and lights, movement and time - a peculiar urban perpetuum mobile", which is an effect of permeating and overlapping of different historical periods and cultural strata (Pęckowska 2012: 83-84). Architects are also interested in the immobile, stable and permanent background of the social life which takes place in a city, serving as a point of one's spatial orientation and giving people a sense of security and a symbolic shield.

A consistent reflection both on the essence of time and space in geographical research may be found in the second half of the $20^{\text {th }}$ century, being - similarly to most social studies - a result of crucial philosophical and methodological changes which led to reinterpreting the basic categories of reality. The previously 
predominant naturalistic approach was juxtaposed with a humanistic approach, whereas the concept of objective nature of reality, independent from people's perceptions and needs, was confronted with a constructivist approach which emphasized the fact that reality is created by societies.

From the perspective of geography, the category of time is a particularly significant yet complex issue, since it constitutes - together with space - a fundamental dimension of human reality. Unlike space, time cannot be expressed geographically; it is, however, just like space, a key element of the social life. People live in certain space-time which consists of at least a few overlapping perspectives - from the macro perspective - the time of an era, time of culture, most frequently referred to by architects, urbanists and anthropologists, through the mezzo perspective - generations, to the micro perspective - personal time and everyday functioning, which is of particular interest for sociologists and social psychologists. People shape and use space in accordance to their current models and ideas, simultaneously experiencing and reading symbols written in this space in the past. Thus, there occurs accumulation of time, and space embeds time, opening an area of interest for geographers and geography, which may constitute a synthesis of all previously characterized perspectives.

The geography of time concerns "chronogeography" (time and space), i.e. the "individual existence" in the scale of a day, year or entire life (biogeography). The categories of time geography encompass the physical existence and life pathways of both people and the products of their activity, which makes it also possible to trace the evolution of landscape, i.e. its origins, changes, evaluation of its inhabitants and other users. By superimposing these two dimensions - space and time, it is possible to grasp the dynamics of the reality. Cities, as historical phenomena which have undergone various changes, make it possible to identify successive layers of time imprinted in their urban landscape, and thus may constitute a particular subject for a broad, interdisciplinary reflection on the complex essence of time. Separating time from space, which was postulated by Immanuel Kant ${ }^{2}$, is impossible here (Thrift 1977, after: Węcławowicz 1983).

There are four geographical perspectives of defined relations between time and space which have occurred in the works of geographers over the last century. The first two: "space outside of time" and "time outside of space" emphasized only one of the dimensions. The other one, if it appeared at all in analyses, constituted their background or, at best, served as an explanatory variable. The third perspective defines time and space as co-dependent, yet still differentiates between them as

${ }^{2}$ Time and space belong to the categories used by Immanuel Kant to divide the entire knowledge about the world. Following this division, geography encompasses all aspects which refer to space, whereas history encompasses all aspects referring to time. This dichotomy did not only delimit the research area of these disciplines for two centuries, but also affected their research methods. 
two separate categories (Agnew 1998; Massey 1999, 2005; Crang 2001). Finally, in the fourth perspective, time and space are treated as one, uniform analytical category referred to as space-time (Wallerstein 1998; May, Thrift 2001).

Time, interpreted broadly in urban space, serves as a measure of changeability and movement, which refer to both the evolution of the landscape by continual development of a city and overlapping of cultural strata, as well as a characteristic tempo and rhythm of everyday life, both in the sense of collective and individual practices. Both dimensions of changeability and movement of urban space constitute a "mirror" of social relations of successive generations of inhabitants, i.e. a mirror which records space. The time dimension of the social life in a city, which translates into particular spatial practices, may be depicted on the basis of three platforms which permeate one another (Table 1), i.e. (1) long duration longue dureé, associated with centuries-old shaping of the essential frameworks of social life; (2) lifespan dasein, in which an individual cycle of man's life or family life is encompassed in social life; (3) duration of daily life dureé of daily life, determined by the rhythm of everyday practices which are closely related both to the institutional surroundings and an individual life cycle. Similarly, also based on three platforms, we may illustrate the spatial dimension of social life in a city. The broadest of the three are spatial practices which lead to shaping of space by entire societies. Another one is a place, interpreted by the meanings which are ascribed to city space by its users. Finally, there are individual spatial practices referring to the interactions between people and their personal space. All the platforms of time and space overlap with one another, creating a multi-dimensional image of the city's space-time, in which man functioned in the past, functions in the presence and will function in the future. It shall be added that T. Hägerstrand's suggestion of time geography fills only the last field of the matrix of relations between space, time and man.

Table 1. Time, space and social life

\begin{tabular}{|c|c|c|c|}
\hline Space & $\begin{array}{l}\text { Long duration } \\
\text { Longue dureé }\end{array}$ & $\begin{array}{l}\text { Lifespan } \\
\text { Dasein }\end{array}$ & $\begin{array}{l}\text { Duration of daily life } \\
\text { Dureé of daily life }\end{array}$ \\
\hline $\begin{array}{l}\text { Collective spatial } \\
\text { practices }\end{array}$ & $\begin{array}{l}\text { Social and spatial } \\
\text { development } \\
\text { (historical time) }\end{array}$ & $\begin{array}{l}\text { Life strategies in } \\
\text { spatial context }\end{array}$ & $\begin{array}{l}\text { Geographical } \\
\text { conditions for } \\
\text { everyday spatial } \\
\text { practices }\end{array}$ \\
\hline Place & $\begin{array}{l}\text { Local history, } \\
\text { culture, traditions }\end{array}$ & $\begin{array}{l}\text { Identity, } \\
\text { geobiography }\end{array}$ & Valuating space \\
\hline $\begin{array}{l}\text { Individual spatial } \\
\text { practices }\end{array}$ & $\begin{array}{l}\text { Historical and } \\
\text { cultural conditions } \\
\text { for spatial practices }\end{array}$ & $\begin{array}{l}\text { Life strategies versus } \\
\text { spatial practices }\end{array}$ & $\begin{array}{l}\text { Everyday spacetime } \\
\text { rhythm } \\
\text { (time geography) }\end{array}$ \\
\hline
\end{tabular}

Source: self-prepared by the author on the basis of K. Simonsen (1991). 


\section{Methodology}

The issue of time in urban space discussed in this paper belongs to the field of human geography, the subject of which are people and their experiences. An access to this world may be reached through the signs of expressions in which it expresses itself. The methodology of human geography assumes the possibility of an indirect insight into human consciousness through observing its expressions such as: utterances, gestures, works of art. It is made possible owing to a wide range of methods - from phenomenology through hermeneutics, semiology, linguistics to structuralism - thanks to which we are able to look at a city from a different perspective - to get to the source of human knowledge concerning urban space-time.

The key empirical material in this paper is composed of 197 photo essays $^{3}$ prepared in the years 2011-2016 by the $2^{\text {nd }}$-year MA-program students of geography at the University of Lodz, within the framework of the project "My image of Lodz", as part of the course on "The image of urban space". The students constituted a deliberately selected group of young people who are generally assumed to be the most attentive and critical observers of the reality (Mordwa 2003). Furthermore, a five-year training in geography made it possible to regard them as experts, particularly sensitive to the surrounding space. The students were asked to use their own cameras to present various places within the following categories being interrelated to perceptions of various dimensions of time (rhythm, tempo, changeability, cyclicality, repetitiveness: "a place where time passes fast", "a place where time slows down", "a place where time has stopped", "a place where one can see development", "a place where one can see crisis" and also duration and evanescence for the category of "a place which tells the story of the city". Various features of time appeared also in other categories of places (e.g. "a place which brings about positive emotions"). The photographs expressed and distilled individual social reflections upon urban space, and constituted visual data for further quantitative and qualitative interpretation, as each picture had to be equipped with a caption of about 50-60 words - a justification for the choice of a given place or object.

The first perspective applied a method of a structural analysis of a photograph, which makes the image - separated from its author - the main subject of interpretation. Its character is mainly substantive, factual, aiming at discovering numerous levels in which social and cultural meanings are hidden together with

\footnotetext{
${ }^{3}$ In English literature, this method is referred to as a "photo-projective method", "photo-production" or "self-directed photography". One may also find in this method a few elements similar to the most characteristic method applied in geographic research on experiencing time, that is time-space diaries (see more in: Schwanen 2009).
} 
the code to understand these meanings (Sztompka 2005). Attention was paid to the places depicted in the photographs, the time when the photographs were taken (season, part of day) and time attributes associated with the place being photographed (old-new, fast-slow, dynamic-stable).

What should be highlighted here is the fact that the role of photography as a research method in social sciences is becoming more and more significant. The relationship between the geographical knowledge and analysis of visual representations of space has been the subject matter of a few studies, including M. Crang (1997) and G. Rose (2000, 2008), who emphasized the role of geographers in explaining the manners of presenting landscapes and places. The freedom and possibility of an individual interpretation of space while taking photographs, which is difficult to attain while conducting standard social research, are among the most frequently stressed advantages of applying visual methods in contemporary studies. Furthermore, despite the subjectivity of experiences and assessments of individual persons, as well as the freedom of the photography method, most images may be read as an illustration of typical impressions, common to all participants of the research.

The photographs which were included in the photo essays fulfil all five functions of photography in social studies referred to by P. Sztompka (2005) (1) stimulating attention and imagination during observation, which translates into a deliberate selection of photographed subjects, objects, events, contexts, recording experiences and impressions; (2) heuristic inspiration - photographs which are more suggestive than written words serve as a particular invitation to deduce, speculate and interpret the world from a wider perspective; (3) registration and recording of visual facts in a certain temporal and spatial context; (4) a pretext for a group discussion or a photo interview, which facilitates interest and mobility of the participants of social studies; (5) an illustration of concepts, categories and regularities of the social reality, which helps in its visual presentation.

Descriptions explaining the choice of particular categories of places which accompanied all photographs were analyzed with the use of a semantic field technique devised by R. Robin (1980). This technique consists in searching for words and phrases which appear in an analyzed text (in our case these are the descriptions which interpret particular photographs in the photo essays), forming a network of relations with the analyzed concepts (key words and phrases), and which make it possible to read their full meaning and the context in which they appear. This technique derives from linguistic studies which began in the 1930s. It may also be associated with a qualitative text analysis or discourse analysis. Analyzing the semantic field consists in separating the elements of a statement only to put them back together in accordance with their meaningful readability. The process is based on building an inventory consisting of: 
- Definitions - indicating the features of the subject; (what it is like - the essence or demeanour of the subject);

- Associations - indicating what the subject is associated with, what it entails;

- Oppositions - indicating the opposites of the subject;

- Equivalents - expressions which may substitute the subject in particular contexts - what the subject is identified with;

- Actions towards the subject - indications of the activities performed for the subject;

- Actions of the subject - indications of the subject's activities and their effects (Fig. 1).

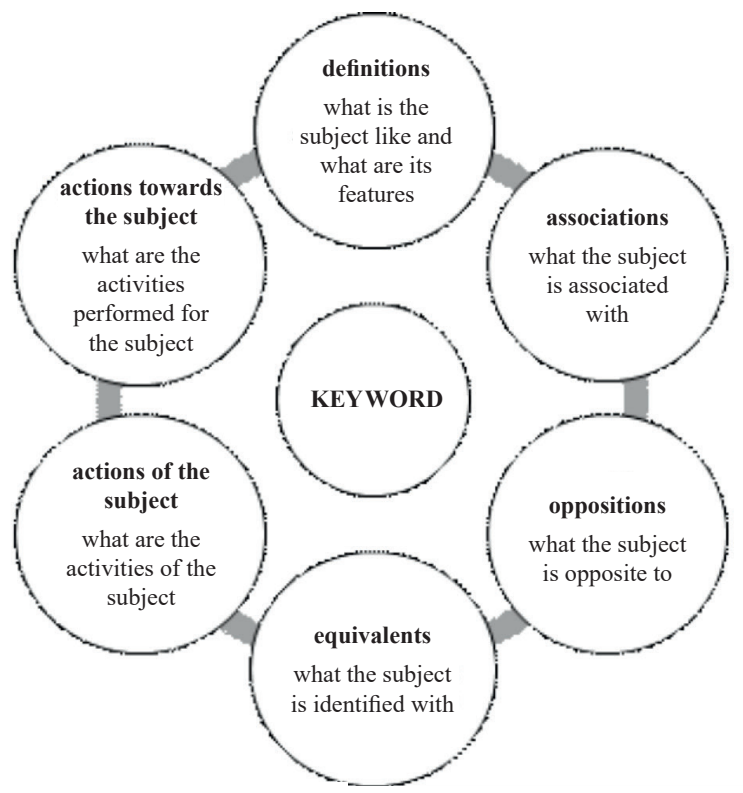

Fig. 1. The structure of the semantic field analysis

Source: author's self-analysis on the basis of R. Robin (1980).

In this manner, an analysis was conducted of definitions regarding different contexts of time in the urban space enabling to redefine them from the perspective of social experiences and expectations concerning the city space-time.

\section{The cemetery - the place where time slows down and finally stops}

In the context of time defined as the "accompaniment for movement and change", where time is assumed not to be measurable, but intuitively felt, students indicated such places in a city of Lodz where time flies fast and where in their opinion, time slows down. This was the way to go to present the contrasting, uneven and unstable space of the modern city - related to the subjective sense of unequal 
expiry of time, depending on where we are and what we do. Cemeteries were the main category of places to be presented as these where the time "slows down" and where the time "has stopped". Especially understanding of the latter category seemed to contain a deeper, existential dimension.

Composition of the semantic field, based on statements about "places where time slows down" accompanying photographs in photo essays, shows that these were most often identified with quietness and silence, lack of haste, the ability to break away from the everyday rush of the city, to forget about everyday duties (Table 2).

Such places, according to the authors of photo essays, are primarily green spaces - composing "oasis in the urban jungle", where contact with nature allows for rest. Many associations involved churches and cemeteries, which, despite their location - often in the very heart of the city, are a refuge of silence. Their sacred space breaks the urban profane space, stops its momentum, calms the noise, calms down. At the threshold of the church or at the gate of the cemetery not only the continuity of space, as was written by M. Eliade (2008), but also the continuity of time is interrupted.

"The Old Cemetery in Ogrodowa Street is a place where time passes slowly [...] It's a place that I associate with silence, calmness [...] with slowly passing time $[\ldots]$ where there is not crowded, there are not many people [...]" (essay 57/2013, woman, a resident of Lodz since 2008).

"The Old Cemetery is a place where time passes slowly. It is the most beautiful cemetery in Lodz, where most important people for the city rest in peace. The cemetery is a place where every person pauses for a moment to wonder about the meaning of his life" (essay 43/2014, female, a resident of Lodz since birth).

Table 2. Semantic field for the category of the "place where the time slows down"

\begin{tabular}{ll}
\hline \multicolumn{1}{c}{ Elements of the semantic field } & \multicolumn{1}{c}{ Fragments of photo essays } \\
\hline Definitions & Calm, silent, peaceful, oasis, of slow changes \\
\hline Associations & $\begin{array}{l}\text { Contact with nature, greenery, far from the traffic and } \\
\text { noise of surrounding streets, minimum movement, } \\
\text { lazy atmosphere of slow walks, queue, place of } \\
\text { silence and reverie }\end{array}$ \\
\hline Oppositions & Fast movement, noise \\
\hline Equivalents & $\begin{array}{l}\text { Place to rest, far from the rush of the city center, the } \\
\text { collapse of the timespace continuum }\end{array}$ \\
\hline Actions of the subject & $\begin{array}{l}\text { Allows to break away from the everyday rush, take } \\
\text { rest from the city, take a deep breath, forget about } \\
\text { duties, invites us to reflect on lifespan }\end{array}$ \\
\hline Actions towards the subject & "I recommend", "I am always willing to be back" \\
\hline
\end{tabular}

Source: author's self-analysis based on photo essays. 
Interpretations of the "places where the time has stopped" broaden the discussion about the time subjectively perceived in the city space, in the context of the everyday experience of varying pace of movement and change. In this way, apart from the places in which the city seems to accelerate and slow down, information has been obtained about such parts of Lodz, where there is no movement, where there have been no changes over the years.

An analysis of the semantic field for the statements centered around "places where time has stopped", presents them as an oasis of peace, places "detached" from the rest of the city, unchanging for years, making them look like old photographs, being a kind of journey into the past (Table 3). In this case the statements of the authors of the various essays were very emotional and consisted a deeper, existential dimension. They referred to the categories of duration, transience and memory. Attention was paid to the specific atmosphere of places that seem to be "guarding history", forcing them to reflect on the passing of time and the passing life.

Table 3. Semantic field for the category of the "place where the time has stopped"

\begin{tabular}{ll}
\hline \multicolumn{1}{c}{ Elements of the semantic field } & \multicolumn{1}{c}{ Fragments of photo essays } \\
Definitions & $\begin{array}{l}\text { Oasis of peace, outer world, ,raisin" in the city rush, } \\
\text { place where the city has stopped, place detached } \\
\text { from the surrounding, unchangeable place, place of } \\
\text { memories and reverie }\end{array}$ \\
\hline Associations & $\begin{array}{l}\text { Unique atmosphere, looks like from old photographs, } \\
\text { old, small, wooden, historic }\end{array}$ \\
\hline Oppositions & Modernity, development, change \\
\hline Equivalents & The end, journey to the past \\
\hline Actions of the subject & $\begin{array}{l}\text { Symbolises peace and tranquility, transfers in time, } \\
\text { looks like in times of its glory, calms down, upholds } \\
\text { history, creates the atmosphere of the past }\end{array}$ \\
\hline Actions towards the subject & $\begin{array}{l}\text { Restoration works, must be preserved, target for } \\
\text { tourists }\end{array}$ \\
\hline
\end{tabular}

Source: author's self-analysis based on photo essays.

These fragments of the city space of Lodz, interpreted as places where the time has stopped included primarily old cemeteries: Old Cemetery in Ogrodowa Street and Jewish Cemetery. Also, the oldest church in Lodz, St. Joseph's (Photo 1). In this case, as in the category of "places where the time slows down", they were referred to their metaphysical character. Especially in the case of cemeteries, time has stopped both in the literal sense, in the perspective of the 
inevitable end of human existence, but also in the broader sense of the passing of the city, in this case the multicultural community of Lodz composing the city in the $19^{\text {th }}$ century.

"Old cemetery is a place where for many people the time has stopped. It tells the story of both ordinary and very important people who created this city in the past. A place that has not changed for years. Makes the impression of being asleep and encouraging reflection" (essay 53/2015, female, a resident of Lodz since 2010).

"Catholic church. St. Joseph. A small, isolated wooden temple. Its view brings to mind the times of agricultural Lodz. Who else still remembers this? The spirit of this church is guarding history, create the atmosphere of the past. As you listen carefully, you can hear the sound of carriages and cots. Anyone who wants to move in time for a while should come here" (essay 32/2011, woman, a resident of Lodz since birth).

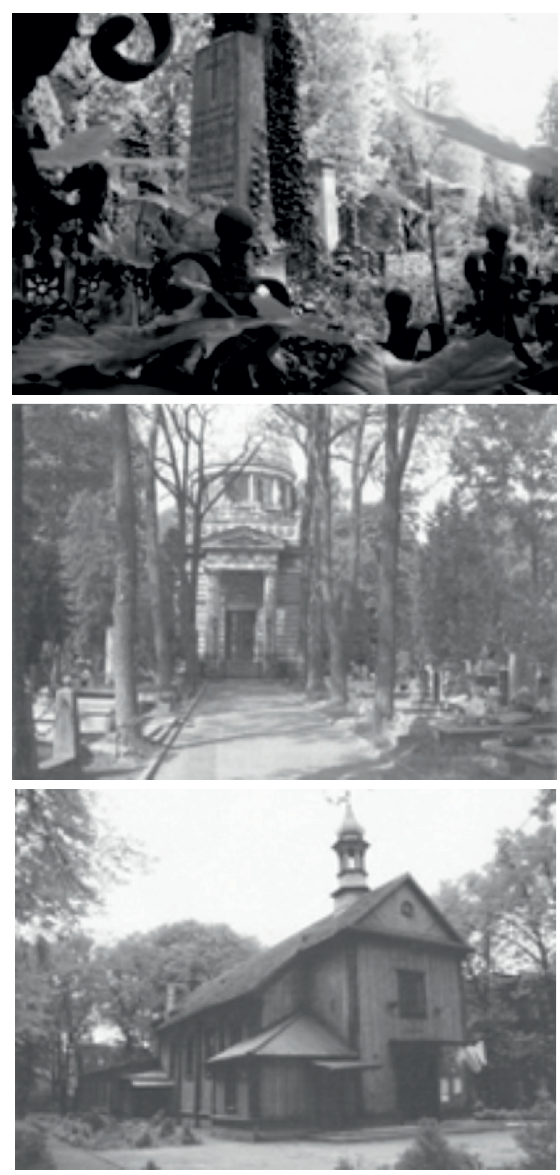

Photo 1. Places where the time "slows down" or "has stopped". Old Cemetery, Jewish Cemetery, St Joseph's Church in Lodz

Source: photo essays. 
Regardless of whether the individual essay referred to church, cemetery or other sacred space, as to the "place where the time slows down" or "has stopped", attention was paid to their deep spiritual dimension, the mystery, the manifestation of God, which Man experiences crossing the boundary of sacrum and profane. The statements in the essays refer to the results of earlier research on the sacred space of the city (eg. Klima 2011) and confirm that these places are extremely important in the daily lives of the locals.

\section{Conclusions}

Time in the urban space constitutes a fundamental attribute of the city and human cognition. It determines the rhythm of the city life, duration and evanescence of successive generations, as well as their social relations reflected in space. Including the perspective of time in analyzing urban space makes it possible to better understand the city structure, as well as the factors which shape people's perception concerning a given place.

Works of geographers indicate the complex nature of time and the manners of its understanding in relation to space, which differ not only among particular societies, but also inside these societies. Of particular importance, here is a shift from objective approaches to those which focus on relative forms of experienced time, as well as from treating time and space separately to the concept of space-time, in which these two categories of reality constitute an inseparable element.

It has been shown in this paper that the dimension of time constitutes a crucial subject for consideration in social sciences, yet a common, broad conception of time has not been attained. Time in city space should be - from a broad perspective - a measure of changeability and movement, which concern both the evolution of the urban landscape through constant development of the city and overlapping of cultural strata, as well as a characteristic tempo and rhythm of the city's everyday life in the sense of collective and individual practices. Both the dimensions of changeability and movement constitute a certain "mirror" to social relations of successive generations of inhabitants recorded by space.

Cemeteries as they are the symbols of the past, recorded in the space of Lodz, constitute a vital element in creating local identity and positive relations between people and their surroundings, as according to statements in their photo essays, they wish to have modern city space, yet they also need to be anchored in the past. This anchor may be just a minor detail in modern space, but its power of influence on the evaluation of space by the inhabitants is large. In this respect, Lodz offers a number of possibilities - the well-preserved heritage of its history enriches its contemporary space, making it stand out among other large cities in Poland.

According to the photo essays collected between 2011-2016, cemeteries were presented as the main example of the "places where the time slows down" and 
the "places where the time has stopped". Especially understanding of the latter category seemed to contain a deeper, existential dimension. The authors referred to the categories of duration, evanescence and memory. They also highlighted the specific climate of depicted places, which seemed to "uphold history", make us dwell on the passing of time and life.

It seems that the topic touched upon in this work is crucial both from the cognitive and practical perspectives. Further studies in this area might embrace in their scope more cities characterized by a different track of development, thanks to which it would be possible to make broader assumptions concerning the features of time in urban space and the manners of experiencing these two primary dimensions of the reality.

\section{References}

Agnew J., 1998, Geopolitics: Revisioning World Politics, Routledge, London.

Bajcar B., 2000, Wielowymiarowość osobistych koncepcji czasu, "Roczniki Psychologiczne", 3: 71-93.

Crang M., 1997, Picturing practices: Research through the tourist gaze, "Progress in Human Geography", 21: 359-373.

Crang M., 2001, Rhythms of the city: Temporalized space and motion, [in:] May J., Thrift N. (eds.), Timespace: Geographies of Temporality, Routledge, London: 187-207.

Eliade M., 2008, Sacrum i profanum. O istocie religijności, Wydawnictwo Aletheia, Warszawa [oryginalne wydanie: Le Sacré et le Profane, 1956].

Klima E., 2011, Przestrzeń religijna miasta, Wydawnictwo Uniwersytetu Łódzkiego, Łódź.

Leach E.R., 1950, Primitive Calendars, “Oceania”, 20(4): 95-97.

Leach E.R., 1956, Primitive Time Reckoning, "A History of Technology", 1: 110-127, [Singer C., Holmyard E.J., Hall A.R. (eds.)], Oxford at the Clarendon Press.

Leach E.R., 1961, Rethinking Anthropology, Athlone Press, London.

Lévi-Strauss C., 1969, Myśl nieoswojona, Warszawa.

Lévi-Strauss C., 1970, Antropologia strukturalna, Warszawa.

Lynch K., 1972, What Time is This Place?, MIT Press, Cambridge.

Massey D., 1999, Space, time, "science" and the relationship between physical geography and human geography, "Transactions of the Institute of British Geographers", 24(3): 261-276.

Massey D., 2005, For Space, Sage, London.

May J., Thrift N., 2001, Introduction, [in:] May J., Thrift N. (eds.), Time space: Geographies of Temporality, Routledge, London: 1-43.

Mordwa S., 2003, Wyobrażenia miast Polski Środkowej, Wydawnictwo Uniwersytetu Łódzkiego, Łódź.

Pęckowska A., 2012, Pantha Rhei - Ruch i Czas w przestrzeni miejskiej, „Architektura. Czasopismo Techniczne", 109(1): 81-92, Wydawnictwo Politechniki Krakowskiej, Kraków. 
Robin R., 1980, Badanie pól semantycznych: Doświadczenia Ośrodka Leksykologii Politycznej w Saint-Cloud, [in:] Głowiński M. (ed.), Język i społeczeństwo, Warszawa: $1-252$.

Rose G., 2000, Practising photography: An archive, a study, some photographs and a researcher, "Journal of Historical Geography", 26(4): 555-571.

Rose G., 2008, Using Photographs as Illustrations in Human Geography, "Journal of Geography in Higher Education", 32(1): 151-160.

Schwanen T., 2009, Time-Space Diaries, International Encyclopedia of Human Geography, Elsevier Ltd.: 294-300.

Simonsen K., 1991, Towards an understanding of the contextuality of mode of life, "Environment and Planning D: Society and Space", 9: 417-431.

Sztompka P., 2005, Socjologia wizualna, Wydawnictwo Naukowe PWN, Warszawa.

Tobiasz-Lis P., 2016, Czas w przestrzeni miasta. Przykład Łodzi, Wydawnictwo Uniwersytetu Łódzkiego, Łódź.

Wallerstein I., 1998, The time of space and the space of time, the future of social science, "Political Geography", 17(1): 71-82.

Węcławowicz G., 1983, Geografia czasu, „Przegląd Zagranicznej Literatury Geograficznej”, 1, Instytut Geografii i Przestrzennego Zagospodarowania Polskiej Akademii Nauk.

\section{CZAS, PRZESTRZEŃ I ŻYCIE SPOLECZNE NOWA INTERPRETACJA CMENTARZY W MIEŚCIE}

Zarys treści: $\mathrm{W}$ artykule poruszono problematykę czasu zapisanego w przestrzeni miejskiej, wyznaczającego specyficzny rytm, ciągłość i przemijanie kolejnych pokoleń oraz ich relacje społeczne. Zaprezentowano wyniki badań dotyczących postrzegania czasu w przestrzeni cmentarzy, które pozwalają lepiej zrozumieć nie tylko tożsamość tych miejsc w strukturze miasta, ale także czynniki kształtujące wyobrażenia jakie mają o nich mieszkańcy. Prowadzone badania miały głównie charakter jakościowy, wykorzystano metody analizy materiałów wizualnych (zdjęć) oraz pola semantycznego.

Wydaje się, iż wykorzystanie obrazu i słowa otwiera przed geografią człowieka nowe możliwości, nowe źródła eksploracji przestrzeni. Problem podjęty w tekście jest ważny zarówno z poznawczej, jak i praktycznej perspektywy związanej z odpowiednim kształtowaniem przestrzeni miasta - nowoczesnego, a jednocześnie niewykorzenionego z tradycji i tożsamości danego miejsca, w którym ludzie czuliby się dobrze, mogąc odnaleźć zarówno punkt odniesienia do przeszłości, jak i do przyszłości.

Słowa kluczowe: cmentarz, miejsce, przestrzeń, czas, poznanie, geografia człowieka.

Dr Paulina Tobiasz-Lis

University of Lodz

Faculty of Geographical Sciences

Department of Regional and Human Geography e-mail: paulina.tobiasz@geo.uni.lodz.pl 